\title{
Metacognitive Ability Effect on Leadership Development
}

\author{
Emmanuel Mango ${ }^{a^{*}}$, Jeremiah Koshal ${ }^{b}$, Caren Ouma \\ ${ }^{a}$ Kome Business Consultants Limited, Kenya \\ ${ }^{b, c}$ United State International University - Africa, Kenya \\ mangoimmy@gmail.com
}

\begin{abstract}
Leadership is the single most important element for the success of an organization. This explains why leadership skill is one of the most sought after skills. The only challenge is that effective leaders are few. Leadership development is meant to eradicate the shortage of leaders but there is a widespread outcry about the effectiveness of the current leadership interventions. Despite the huge expenditure in developing leaders, the outcomes are not comparable to the resources invested. Beyond the traditional elements (content, context, program length and delivery) of leadership development, the boundaries of research and practices have to be extended to the neglected elements of learning like metacognitive ability, hence this study examines the effect metacognitive ability on leadership development. The study was conducted among MBA students within private universities in Kenya. The sample size was 314 students, with a response rate of 92 percent. The results reveal that metacognitive ability significantly predicts leadership developments. The results imply that the higher the levels of metacognitive ability that leadership development participants have, the better they are at acquiring leadership skills.
\end{abstract}

Article Info

- Received : July 1, 2019

- Revised : August 1,2019

- Published : September 15, 2019

- No. Pages : 279-288

- DOI : $10.33019 /$ ijbe.v3i3.232

- JEL : O15

- Keywords : leadership development, metacognitive ability, leader development readiness

\section{Introduction}

Deloitte Consulting LLP and Bersin [Deloitte] (2014) observes that shortage of leaders is one of the biggest challenges for growth in companies around the world. Every generation has experienced the problem of leadership shortage, but the current generation is in dire need of effective leadership. The leadership needs are not just at the executive level, they are experienced at every level of the organization. The expanding, changing knowledge economy and retiring leaders have created a huge demand for leaders and leadership across the globe. Over 20 percent of the baby boomers in the United States are retiring by the year 2020. At the same time the pace of change in the knowledge economy continues to increase while the global leadership learning curve is becoming longer. These changes have created a shortage of qualified and capable leaders in many organizations (UNC, 2014).

Kuada (2010) argues that the dismal growth of the Sub-Sahara African economies in the past 40 years can be explained by lack of effective leadership in the region. Also, Ward (2016) 
asserts that the hotel industry is expanding rapidly in the Sub-Saharan Africa and as a result, between 2015 and 2020, over 78,000 jobs will be created in the sector. However, the industry, currently, does not have sufficient leaders or potential leaders to meet the projected growth, hence there is urgent need for effective leaders to work in the expanding industry. In a study of the media sector in Kenya, Kiarie, Maru and Cheruiyot (2017) reveals that effective leadership is a predictor of employees' job satisfaction. Ineffective leadership is responsible for the perceptual dissatisfaction that is witnessed in the media sector in Kenya. Njue, Waiganjo and Kihoro (2016) argue that performance challenges experienced by Micro Finance Institutions in Kenya can be solved with effective leadership development. In other words, leadership development affects organizational performance. The Kenyan higher education sector has undergone enormous expansion the past few years; which has led to increase in the number of learning institutions, hence, a greater demand for skilled academic leaders. As a result, the nation does not have the necessary numbers of skilled administrators and lecturers, hence the urgent need for well-skilled leaders to bridge the gap (Mathooko \& Ogutu, 2015). In addition, Asuga, Eacott and Scevak (2015) argue that the education sector like any other sector in Kenya is expanding and there is an urgent need for well-developed academic leadership in Kenya.

The demand for effective leaders is experienced on two fronts. First, majority of the current crop of leaders is regarded as ineffective (Monyoncho (2014). Second, there are increasing opportunities that need well-equipped leaders to fill (Asuga et al. (2015). Given the dire need for effective leaders, urgent steps must be taken to grow leaders that will meet the increasing demand. Whereas, many scholars, Kellerman (2012) and Snook, Nohria and Khurana (2012), agree that the solution lies with leadership development, the real challenge is how to conduct it in order to produce well-prepared leaders. This study takes on this challenge by examining the effect of metacognitive ability on leadership development.

\section{Literature Reviews}

\section{Leadership Development}

Leadership development is impartation of leadership skills and knowledge among potential leaders (Krauss, Hamid \& Ismail, 2010). Given that shortage of effective leaders is largely attributable to ineffective leadership development, Muteswa (2016), Eckert, Isaakyan \& Mulhern (2014), hence leadership development done right can increase both the quality and number of effective leaders. Despite the recognition that proper leadership development can improve the number and quality of leadership, leadership development remains largely ineffective or insufficient. About 75 percent of the high-potential leadership programs are ineffective (Velayudhan, Gayatridevi, Benedict \& Devi, 2011; Development Dimensions International [DDI], 2015). According to Deloitte's (2014), survey revealed that while 86 percent of the respondent's regard leadership development as urgent and important, only 13 percent of the respondents are confident about their leadership development initiatives at all levels.

Volz-Peacock, Carson and Marquardt (2016) argue that most leadership development programs are ineffective yet organizations spend billions of dollars on them, and each new year sees an increase in leadership development budget. Kellerman (2012) and DDI (2015) assert that about 50 billion dollars is spent annually on developing leaders around the world but the quality of leadership does not reflect investment. According to Deloitte (2014), about $\$ 15.5$ billion were spent on leadership development in 2013 by US organizations and in 2013 as well as in 2012, each year the leadership development expenditure grew by 14 percent. Given the huge amount of money spent on leadership development one could expect to see leaders that 
are ready to lead at every level of the organization, but the cry for well-prepared leaders says the opposite (Monyoncho, 2014). Organizations are not getting value for the huge sums of money they spend on leadership development. Scholars like, Avolio, Reichard, Hannah, Walumbwa, and Chan (2009), DeGeest and Brown (2011), Reichard and Walker (2016), Nah and Wan (2010), question the logic of concentrating on the traditional aspects of leadership development despite the unsatisfactory results. Given that the current leadership development interventions are yielding disappointing results, it is imperative that researchers and practitioners in the field of leadership development go beyond the traditional research areas of content, context, program length and delivery to include leader developmental readiness (Nah $\&$ Wan, 2010; Reichard \& Walker, 2016). One of the key components of leader developmental readiness is metacognitive ability (Hannah \& Avolio, 2010).

\section{Metacognitive Ability}

According to Lien (2016), Flavell (1979), Hsu (2014), metacognition is thinking about thinking. Metacognitive knowledge is being aware (having an understanding) of your cognitive processes. In general, metacognition can be split into two main components: the metacognitive knowledge and the metacognitive strategy, where "the metacognitive strategy is a higher-order executive skill which includes planning, monitoring and evaluating" (Lv \& Chen, 2010, p.136). Hannah and Avolio (2010) assert that "metacognitive reflection increases depth of processing and can lead to greater self-insight, less maladaptive processing, and changes to deeper selfstructures that can contribute to accelerating [leadership development]" (p. 1184). Metacognitive ability enables learners to know their cognitive strengths and weaknesses, plan, monitor and evaluate their learning in order to achieve the desired learning performance (Lien, 2016).

Learners who utilize metacognitive strategies have been found to have higher learning outcomes as compared to their counterpart who do not utilize those strategies (Soicher \& Gurung, 2017). Metacognition is a predictor of learning proficiency across fields (Hong-Nam, 2014; Knox, 2017). Learners who have a higher metacognitive ability become independent, autonomous (self-directed) and efficient learners. Metacognition is critical in problem solving since it enables people to use knowledge in more contexts than they acquired it (Spellman, Deutsch, Mulder \& Carsten-Conner, 2016). Metacognitive ability gives people confidence in their decisions and enables them monitor for possible errors (Yeung \& Summerfield, 2012). One requires high metacognitive abilities to undertake uncertain or novel cognitive tasks (Haynie, Shepherd \& Patzelt, 2012).

According to Hannah and Avolio (2010), metacognitive ability is a component of developmental readiness that enable learners richer processing and meaning-making concerning developmental experiences. Black, Soto and Spurlin (2016) argue that leaders with higher metacognitive ability have the capacity to reflect on their current knowledge and future knowledge requirement then they seek information and skills that they lack, At the same time they monitor to see if their learning strategies are working or they need to modify them. Metacognitive ability "allows leaders to understand and regulate their thought processes, which contributes to learning and problem solving" (p.86). Leaders with higher metacognitive ability are likely to perform well as leaders because metacognitive ability is related to creative problem solving, decision making, critical thinking and leader performance. Also leaders with better metacognitive ability are better prepared for richer information processing and meaning making, hence, they are likely to benefit more from developmental experiences (Black et al., 2016). 
According to Petrie (2014), leaders are taking over the ownership of their development, for that very reason, Rosch and Anthony (2012) argue that the emphasis should be on learning rather than teaching since it is the student's responsibility to learn. Leaders and potential leaders must know how they learn and how to learn for them to be in charge of their own learning. Petrie argues that the way to make leaders to think in more complex ways and to be more effective is by improving the way leaders make meaning of the world around them (vertical development), which is based on improving the leaders' metacognitive ability. Aas (2017) observes that despite the key role played by metacognition in learning leadership, very little research has been conducted to establish the effects of metacognitive process on leadership development.

Velzen (2012) argue that development of expertise in a given area/field is related to the metacognitive knowledge; the higher one's metacognitive ability is the higher the likelihood for them to develop expertise. Different learners apply metacognitive knowledge differently in studying, solving problems and exercising high-order thinking. Learners who are more metacognitive aware are expected to have higher control of their learning. "Metacognitive knowledge provide students with tools for analyzing new information and situations, evaluating prime aspects and searching for improvements" (p.366). Developing higher metacognitive knowledge helps the individual to understand which cognitive processes are required during a given learning situation. Wiltshire, Rosch, Fiorella \& Fiore (2014) argue that understanding and utilization of metacognition strategies goes beyond employee development to application in solving complex problems at work. There is a difference in metacognition of capable learners as compared to less capable learners. High metacognitive ability is a predictor of both developmental and work performance. According to Hong-Nam (2014), metacognitive ability is made up of the ability to plan one's learning, as well as the ability to monitor and control one's learning, thinking and memory.

One of the aspects of individualized leadership development program is a metacognitive learning plan. Forde, McMahon and Gronn (2013) argue that learning plan will aid leaders to succeed in their development. Learners with high metacognitive ability set their learning goals and strategies. They determine what to learn by a given strategy (reasoning, judgment, creativity, among others) and when it can be learnt (Schiff, Ben-Shushan \& Ben-Artzi, 2017). This eliminates trial and error approach and it helps learners to be purposeful in their learning. Leadership development is a complex undertaking that requires the learner to plan how to make sense of the over 66 leadership theories, shifting definition of leadership and ever changing context in which leadership is practiced in.

Leaders too must conduct a self-audit (monitoring and control), to determine whether they are developing as planned or they need to change tact. Individualized leadership development requires the participants to conduct a self-evaluation to discover the strength and weakness with their cognition which helps them plan how to develop (Forde et al., 2013). Monitoring abilities also enable the learners to distinguish between new knowledge and existing knowledge and devise mechanisms (plans, strategies) to learn the new knowledge. Evaluating one's learning enables them to know they can learn quickly and whether they need more time and effort to understand it, hence, they plan appropriately (Johnson, Smyers \& Purvis, 2012).

Learners use their metacognitive knowledge to apply their learning strategy to the task (HongNam, 2014). Those who are aware of their learning strategy are likely to become autonomous learners compared to those who are not aware of their learning strategy (Miller, 2017). People who are aware of their strength and weakness with regard to learning, (Yang, 2016), are capable of evaluating their approaches to learning and at the same time they can evaluate their decisions critically (Yeung \& Summerfield, 2012). People who are aware of their metacognitive abilities 
are able to strategize how they intend to learn, including learning leadership. Effective learners should be aware of their learning and memorizing capabilities and they should also be aware of how to retrieve previous stored information (Hsu, 2010).

\section{Hypothesis}

Based on the literature above the hypothesis for this study is: -

$\mathrm{H}_{01}$ : Metacognitive ability does not have a significant effect on leadership development among the MBA students.

\section{Research Methods}

The study was conducted among MBA students within private universities in Kenya, the study population was $\mathrm{N}=1,721$, while a sample size of $\mathrm{n}=314$ was determined scientifically by Aiken's (1997) formula. The study adopted stratified random sampling method. The metacognitive ability data was collected using a validated tool developed by O'Neil and Abedi (1996). Leadership development and demographic data was collected by tools developed through extensive review of relevant literature and validated through pilot study that was conducted by the first researcher. In order to compare low and high score of metacognitive ability, the scores of metacognitive ability were divided into two groups by use of median. The analyses that were performed in this study included: correlation analysis, One-Way ANOVA and linear regression analysis.

\section{Results}

A response rate of 92 percent (288) was obtained, as shown in figure 1 below.

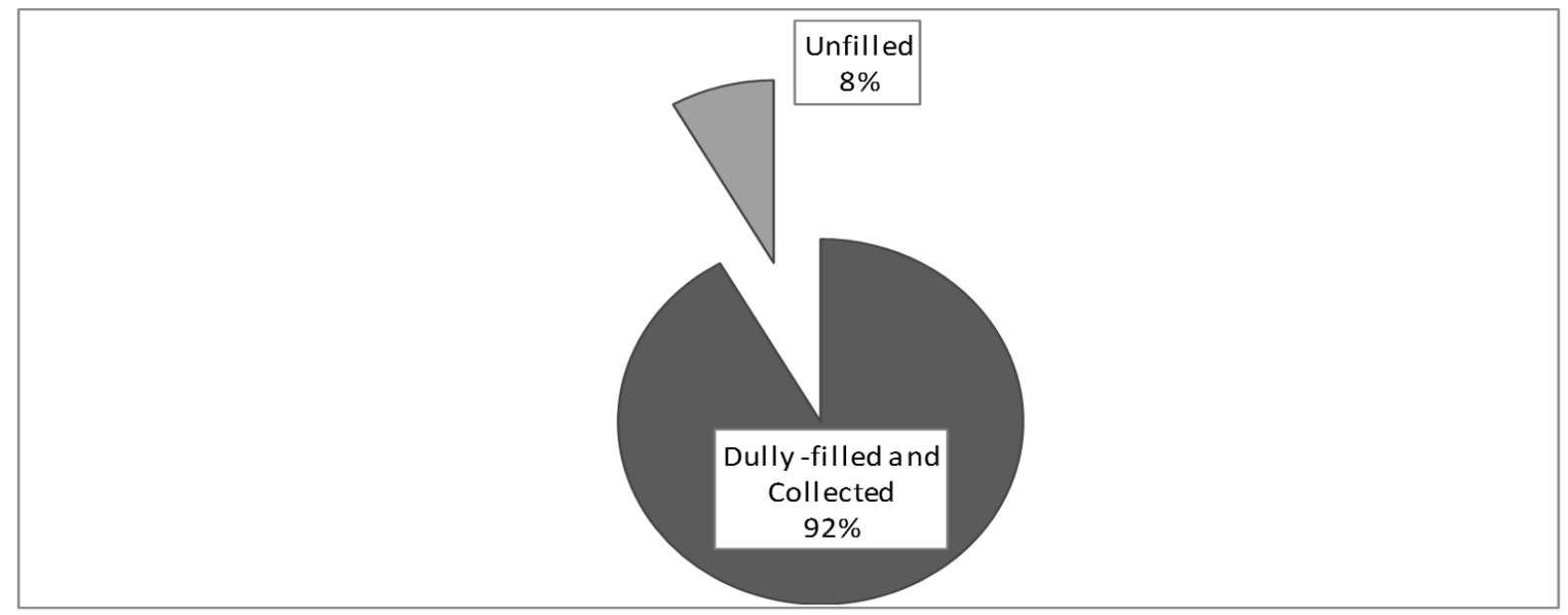

Source: Authors

Figure 1. Response Rate

The respondents aged between 21-30 years were 53.47 percent (154), while those between 3140 years were 34.72 percent (100) and respondents aged between 41-50 years were 11.81 percent (34). The male respondents were 51.39 percent (148), and the female respondents were 48.61 percent (140). The results also showed that 79.17 percent (228) of the respondents were employed/self-employed at the time of data collection, while 15.28 percent (44) of the respondents were employed/self-employed before but not at the time of data collection and only 5.56 percent (16) had never been employed/self-employed. The results revealed that 62.5 percent (180) of the respondents were in managerial/leadership positions at the time of data collection, and only 37.5 percent (108) were not. In addition, the respondents belonged to the 
following industries: non-governmental organizations they were 17.01 percent (49), government they were 15.97 percent (46), corporate they were 61.46 percent (177), while those who were not affiliated to any industry were 5.56 percent (16). Finally, 5.56 percent (16) of the respondents had never worked, 72.92 percent (210) had worked between 1 - 10 years, and 18.01 percent (52) of the respondents had worked between 11 - 20 years, and 3.47 percent (10) of the respondents had worked for 21 years and above.

Correlation analysis was carried out between metacognitive ability and leadership development. The results showed that metacognitive ability and leadership development are significantly correlated, with $\mathrm{r}(288)=.428, \mathrm{p}<.001$, as depicted in table 1 .

Table 1. Correlation between Metacognitive Ability and Leadership Development

\begin{tabular}{|c|c|c|c|}
\hline \multicolumn{2}{|c|}{} & MCA & LD \\
\hline \multirow{3}{*}{ MCA } & Pearson Correlation & 1 & $.428^{* *}$ \\
\cline { 2 - 4 } & Sig. (2-tailed) & & .000 \\
\cline { 2 - 4 } & $\mathrm{N}$ & 288 & 288 \\
\hline \multirow{3}{*}{ LD } & Pearson Correlation & $.428^{* *}$ & 1 \\
\cline { 2 - 4 } & Sig. (2-tailed) & .000 & 288 \\
\cline { 2 - 4 } & $\mathrm{N}$ & 288 & \\
\hline
\end{tabular}

Source: Authors

The results of the One-Way ANOVA showed that the difference between groups' means of metacognitive ability with respect to age, gender, employment status, position, industry and years of experience are all statistically insignificant. On the other hand, the results of the OneWay ANOVA revealed a significant difference in the mean scores between the respondents with low and high metacognitive ability, where $\mathrm{F}(1,286)=28.596, \mathrm{p}<.001$, as shown in table 2 below.

Table 2. ANOVA of Leadership Development with Respect to Metacognitive Ability

\begin{tabular}{|c|c|c|c|c|c|}
\hline & Sum of Squares & df & Mean Square & F & Sig. \\
\hline Between Groups & 22.923 & 1 & 22.923 & 28.596 & .000 \\
\hline Within Groups & 229.263 & 286 & .802 & & \\
\hline Total & 252.186 & 287 & & & \\
\hline
\end{tabular}

Source: Authors

The results in table 3 show that metacognitive ability accounts for $18.3 \%$ variation in leadership development.

Table 1. Model Summary for Regression of LD against MCA

\begin{tabular}{|l|r|r|r|r|r|}
\hline Model & $\mathrm{R}$ & R Square & \multicolumn{1}{|c|}{$\begin{array}{c}\text { Adjusted R } \\
\text { Square }\end{array}$} & $\begin{array}{c}\text { Std. Error of the } \\
\text { Estimate }\end{array}$ & Durbin-Watson \\
\hline 1 & $.428^{\mathrm{a}}$ & .183 & .180 & .84873 & 1.795 \\
\hline
\end{tabular}

a. Predictors: (Constant), MCA

b. Dependent Variable: LD

Source: Authors

The results as shown in table 4 reveal that the model is a significant predictor of leadership development, $\mathrm{F}(1,286)=64.089, \mathrm{p}<.001, \mathrm{R}^{2}=.183$. 
IJBE: Integrated Journal of Business and Economics e-ISSN: 2549-3280

Table 2: ANOVA for Regression of LD against MCA

\begin{tabular}{|l|l|r|r|r|r|r|}
\hline \multicolumn{2}{|l|}{ Model } & Sum of Squares & df & Mean Square & F & Sig. \\
\hline \multirow{3}{*}{1} & Regression & 46.166 & 1 & 46.166 & 64.089 & $.000^{\mathrm{b}}$ \\
\cline { 2 - 7 } & Residual & 206.020 & 286 & .720 & & \\
\cline { 2 - 8 } & Total & 252.186 & 287 & & & \\
\hline
\end{tabular}

a. Dependent Variable: LD

b. Predictors: (Constant), MCA

Source: Authors

Metacognitive ability is a significant contributor to the regression model $(\beta=.381, \mathrm{t}(286)=$ $8.006, \mathrm{p}<.001)$ as shown in table 5.

Table 3: Coefficient for Regression of LD against MCA

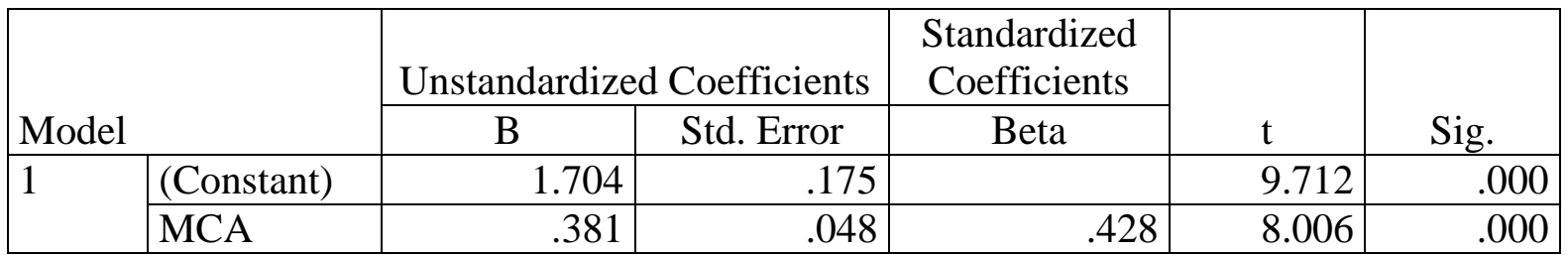

Dependent Variable: LD

Source: Authors

Given that the regression model as shown in table 4 is a significant predictor of leadership development with a $\mathrm{p}<.001$, while the significance level is .05 , the null hypothesis was rejected and the alternative hypothesis was accepted, that is, metacognitive ability has a significant effect on leadership development.

\section{Discussions}

The present study sought to establish whether metacognitive ability had a significant effect on leadership development. In furtherance of this objective, the researcher performed correlation analysis, One-Way analysis of variances and regression analysis of leadership development with respect to metacognitive ability. The correlation analysis revealed that metacognitive ability is positively and significantly correlated with leadership development, $r(288)=.428$, $p$ $<.001$. The results in this study agree with Lien (2016) that metacognitive ability correlate with learning outcomes. The results indicate that respondents with high metacognitive ability scores also have high leadership development scores. The One-Way analysis of variances results revealed that there is a significant difference in leadership development mean scores of respondents with low metacognitive ability and respondents with high metacognitive ability, $\mathrm{F}(1,286)=28.596, \mathrm{p}<.001$. The results indicate that respondents with low metacognitive ability scores also had low leadership development scores, while respondents with high metacognitive ability scores also had high leadership development scores.

Regression analysis results revealed that metacognitive ability is a significant predictor of leadership development, $\mathrm{F}(1,286)=64.089, \mathrm{p}<.001, \mathrm{R} 2=.183$. The findings in the present study support those of Hong-Nam (2014). The results indicate that metacognitive ability scores forecast the scores for leadership development all other factors held constant. The results show that metacognitive ability significantly affects leadership development. This supports Velzen (2012), who argues that metacognitive ability affects development of expertise in numerous fields. Miller (2017) as well as Zion, Adler and Mevarech (2015) similarly arrived at the same conclusion, metacognition that affects learning outcomes. Leaders with high metacognitive ability take every opportunity as a learning opportunity (Robertson, 2013). The results show 
that leadership developers should take into consideration metacognitive ability and activities aimed at boosting it in designing and delivering leadership development initiatives. Given the important role played by metacognitive ability in leadership development, the qualitative analysis below highlights some of the attributes that increase leadership learners' metacognitive abilities.

Given that the study established that metacognitive ability means scores of different groups, with regard to the different demographic factors (age, gender, employment status, position, industry and years of experience), are not significantly different. This may inform the approaches that may be adopted in boosting metacognitive ability. The results imply that in designing and developing metacognitive boosting initiatives, leadership developers should not take into account the age, gender, employment status, position, industry and years of experience of the participants.

\section{Conclusion and Suggestion}

\section{Conclusion}

The study goes on to show that metacognitive ability significantly affects leadership development. It indicates that individuals with high metacognitive ability also obtain high scores in leadership development, while individuals with low metacognitive ability scores also obtain low scores in leadership development. It is not surprising that people who plan and strategize how and what to learn score highly in leadership development. They also monitor and control their learning, they take time to examine if they are making progress in learning leadership and if they aren't, they devise alternative approaches to better their learning. The respondents know their learning strength and weakness, hence they are able to make use of their strength and minimize their weakness in learning leadership. All these factors taken together, may explain why respondents with high metacognitive ability score highly in leadership development. All the demographic factors in this study (employment status, position, industry, years of experience, age and gender) do not matter in improving one's metacognitive ability.

\section{Suggestion}

The problems that leadership face today cannot be solved by easy answers; leaders must be helped to develop their metacognitive ability because it helps them to engage in high order thinking which is vital both in developing as leaders and in the practice of leadership. Organizations should ensure that leaders are aware of their learning capabilities, know how to plan, monitor and control their learning. This will help the leaders to effectively learn leadership and also to deal with constant changes at the workplace. Further study should also be conducted to establish why demographic factors (age, gender, employment status, position, industry and years of experience) have no effect on metacognitive ability.

\section{References}

1) Aas, M. (2017). Leaders as learners: developing new leadership practices. Professional Development in Education, Vol. 43, No. 3, pp. 439 - 453.

2) Aiken, L. (1997). Questionnaires and inventories. New York, NY: John Wiley \& Sons.

3) Asuga, G., Eacott, S., \& Scevak, J. (2015). School leadership preparation and development in Kenya: Evaluating performance impact and return on leadership development investment. International Journal of Educational Management, Vol. 29, No. 3, pp. 355-367. 
4) Avolio, B., Reichard, R., Hannah, S., Walumbwa, F., \& Chan, A. (2009). A Meta-analytic review of leadership impact research: Experimental and quasi-experimental studies. Leadership Quarterly, Vol. 20, pp. $764-784$.

5) Black, H., Soto, L., \& Spurlin, S. (2016). Thinking about thinking about leadership: Metacognitive ability and leader developmental readiness. New Directions for Student Leadership, Vol. 149, pp. $85-95$.

6) DDI (2015). Ready-now leaders: 25 findings to meet tomorrow's business challenges - the global leadership forecast 2014-2015.

7) DeGeest, D., \& Brown, K. (2011). The role of goal orientation in leadership development programs. Human Resources Development Quarterly, Vol. 22, No. 2, pp. 157 - 176.

8) Deloitte (2014). Global human capital trends: Engaging the 21st-century workforce.

9) Eckert, R., Isaakyan, S., \& Mulhern, W. (2014). The effectiveness of the leadership development programme in Europe: An evaluation report. Greensboro, NC: Center for Creative Leadership.

10) Flavell, J. (1979). Metacognition and cognitive monitoring: A new area of cognitive developmental inquiry. American Psychologist, Vol. 34, No. 10, pp. 906 - 911.

11) Forde, C., McMahon, M., \& Gronn, P. (2013). Designing individualized leadership development programmes. School Leadership \& Management, Vol. 33, No. 5, pp. 440 - 456.

12) Hannah, S., \& Avolio, B. (2010). Ready or not: How do we accelerate the developmental readiness of leaders? Journal of Organizational Behaviour, Vol. 31, pp. 1181 - 1187.

13) Haynie, J., Shepherd, D., \& Patzelt, H. (2012). Cognitive adaptability and an entrepreneurial task: The role of metacognitive ability and feedback. Entrepreneurship Theory and Practice, pp. 237 265.

14) Hong-Nam, K. (2014). ELL high school students' metacognitive awareness of reading strategy use and reading proficiency. TESL-EJ, Vol. 18, No. 1, pp. $1-16$.

15) Hsu, L. (2014). Factors affecting metacognition of undergraduate nursing students in a blended learning environment. International Journal of Nursing Practice, Vol. 20, pp. 233 - 241.

16) Hsu, L. (2010) Metacognitive inventory for nursing students in Taiwan: Instrument development and testing. Journal of Advanced Nursing, Vol. 66, No. 11, pp. $2573-2581$.

17) Johnson, J., Smyers, J., \& Purvis, R. (2012). Improving exam performance by metacognitive strategies. Psychology Learning and Teaching, Vol. 11 No. 2, pp. $180-185$.

18) Kellerman, B. (2012). The End of leadership. New York, NY: HarperCollins.

19) Kiarie, M., Maru, L., \& Cheruiyot, T. (2017). Leader personality traits and employee job satisfaction in the media sector, Kenya. The TQM Journal, Vol.29, No. 1, pp. 133 - 146.

20) Knox, H. (2017). Using writing strategies in math to increase metacognitive skills for the gifted learner. Gifted Child Today, Vol. 40, No. 1, pp. $43-47$.

21) Krauss, S., Hamid, J., \& Ismail, I. (2010). Exploring trait and task self-awareness in the context of leadership development among undergraduate students from Malaysia. Sage Publications. Vol. 6, No.1, pp.3- 19.

22) Kuada, J. (2010). Culture and Leadership in Africa: A conceptual model and research agenda. African Journal of Economic and Management Studies, Vol.1, No.1, pp. 9-24.

23) Lien, H. (2016). Effects of EFL individual learner variables on foreign language reading anxiety and metacognitive reading strategy use. Psychological Reports, Vol. 119, No. 1, pp. $124-135$.

24) Lv, F., \& Chen, H. (2010). A study of metacognitive-strategies-based writing instruction for vocational college students. English Language Teaching, Vol. 3, No. 3, pp. 136-144.

25) Mathooko, F., \& Ogutu, M. (2015). Porter's five competitive forces framework and other factors that influence the choice of response strategies adopted by public universities in Kenya. International Journal of Educational Management, Vol. 29, No. 3 pp. 334 - 354.

26) Miller, G, (2017). Metacognitive awareness and reading strategy use: investigating the intermediate level ESL students' awareness of metacognitive reading strategies. St. Cloud State University, retrieved on 31/08/2018, from http://repository.stcloudstate.edu/engl_etds/115

27) Monyoncho, R. (2014). The leadership dilemma: An African perspective - Confronting Africa's governance challenges in 21st century. Nairobi, KE: Aura Publishers.

28) Muteswa, R. (2016). Qualities of a good leader and the benefits of good leadership to an organization: A conceptual study. European Journal of Business and Management, Vol. 8, No. 24, pp. $135-140$. 
29) Nah, C., \& Wan, K. (2010). Understanding developmental readiness. Retrieved September 13, 2016, from https://www.cscollege.gov.sg/knowledge/Pages/Understanding-DevelopmentalReadiness.aspx

30) Njue, N., Waiganjo, E., \& Kihoro, J. (2016). Influence of coaching as a leadership practice on the performance of microfinance institutions in Kenya. International Journal of Academic Research in Business and Social Sciences, Vol. 6, No. 10, pp. $206-217$.

31) O'Neil, H., \& Abedi, J. (1996). Reliability and validity of a state metacognitive inventory: Potential for alternative assessment. Journal of Educational Research, Vol. 89, No. 4, pp. 234 - 245.

32) Petrie, N. (2014). Future trends in leadership development. Greensboro, NC: Center for Creative Leadership.

33) Robertson, J. (2013). Learning leadership: Leading and managing, Vol. 19, No. 2, pp. 54 - 69.

34) Rosch, D., \& Anthony, M. (2012). Leadership pedagogy: putting theory to practice. New Directions for Student Services, Vol. 140, pp.37 - 51.

35) Schiff, R., Ben-Shushan, Y., \& Ben-Artzi, E. (2017). Metacognitive strategies: A foundation for early word spelling and reading in kindergartners with SLI. Journal of Learning Disabilities, Vol. 50, No. 2, pp. $143-157$.

36) Soicher. R., \& Gurung, R. (2017). Do Exam wrappers increase metacognition and performance? A single course intervention. Psychology Learning \& Teaching, Vol. 16, No. 1, pp. 64 - 73.

37) Snook, S., Nohria, N., \& Khurana, R. (2012). The handbook for teaching leadership: Knowing, doing and being. Los Angeles, CA: Sage.

38) Spellman, K., Deutsch, A., Mulder, C., \& Carsten-Conner, L. (2016). Metacognitive learning in the ecology classroom: A tool for preparing problem solvers in a time of rapid change? Ecosphere, Vol. 7, No. 8, pp. $1-19$.

39) UNC (2014). UNC leadership survey 2014: How to accelerate leadership development.

40) Velayudhan, A., Gayatridevi, S., Benedict, N., \& Devi, A. (2011). Leadership development intervention: An experimental study. Asia-Pacific Business Review, Vol. 7, No. 2, pp. 178 - 188.

41) Velzen, J. (2012). Teaching metacognitive knowledge and developing expertise. Teachers and Teaching: Theory and Practice, Vol. 18, No. 3, pp. 365 - 380.

42) Volz-Peacock, M., Carson, B., \& Marquardt, M. (2016). Action learning and leadership development. Advances in Developing Human Resources, Vol. 18, No. 3, pp. 318 - 333.

43) Reichard, R., \& Walker, D. (2016). In pursuit: Mastering leadership through leader developmental readiness. New Directions for Student Leadership, Vol. 149, pp. 15 - 25.

44) Ward, T. (2016). Hotel chain development pipelines in Africa: Implications for human capital development. Worldwide Hospitality and Tourism Themes, Vol. 8, No. 2, pp.134 - 148.

45) Wiltshire, T., Rosch, K., Fiorella, L., \& Fiore, S. (2014). Training for Collaborative Problem Solving: Improving Team Process and Performance through Metacognitive Prompting. Proceedings of the Human Factors and Ergonomics Society 58th Annual Meeting, pp. 1154-1158

46) Yang, Y. (2016). A research on reading strategies among Non-English major postgraduates. English language teaching, Vol. 9, No. 8, pp. 204 - 212.

47) Yeung, N., \& Summerfield, C. (2012). Metacognition in human decision-making: confidence and error monitoring. Philosophical Transactions: Biological Sciences, Vol. 367, No. 1594, pp. 1310 1321.

48) Zion, M., Adler, I., \& Mevarech, Z. (2015). The effect of individual and social metacognitive support on students' metacognitive performances in an online discussion. Journal of Educational Computing Research, Vol. 52, No.1, pp. 50 - 87. 